\title{
Zoogeographic Characteristics of the Yakutian Tabanid (Diptera, Tabanidae) Fauna
}

\author{
A. I. BARASHKOVA* AND A. D. RESHETNIKOV \\ FRS YaSC SB RAS Yakut Scientific Research Institute of Agriculture named after M. G. Safronov, Bestuzhev- \\ Marlinsky Street, 23/1, Yakutsk, 677001, Russia \\ *(e-mail : aibarashkova@mail.ru; Telephone : 8 (4112) 21-45-74)
}

(Received : April 2, 2019; Accepted : June 20, 2019)

\begin{abstract}
Twenty-one species and one subspecies of tabanids belonging to two genera have been established on cattle and horse pastures in Central Yakutia as follows : Chrysops (6 species) and Hybomitra (15 species and one subspecies). In addition, varieties (dark forms) of two types have been found, namely, Hybomitra bimaculata var. bisignata and $H$. montana var. flaviceps. In Central Yakutia, the Hybomitra genus is distinguished by the greatest species diversity. Hybomitra montana montana (DI 45.29\%), H. lundbecki lundbecki (DI 24.97\%) and H. ciureai (DI $11.20 \%$ ) have been the dominant ones, H. arpadi (DI 5.85\%), H. nitidifrons (DI 4.03\%) and H. nigricornis (DI 2.97\%) sub-dominant. In total, these species accounted for $94.31 \%$ of the collections. Two more species H. lurida (DI 1.88\%) and H. lundbecki sibiriensis (DI $1.13 \%$ ) have been small in number, accounting for $3.1 \%$ in the collections. The remaining 13 species and one subspecies refer to the group of rare ones and make up $2.59 \%$ in the collections. The mixed zoogeographical structure of the tabanid fauna of Central Yakutia, which is part of the middle taiga subzone, consists of three types of Palearctic fauna : Boreurasian (19 species, one subspecies), arid Afro-Eurasian (one species) and East Asian (one species). The Boreurasian type is distinguished by the greatest species diversity. The Boreurasian fauna species belong to four faunistic complexes as follows : tundra two species taiga 14 species and one subspecies, East Siberian forest one species, and forest-steppe two species. The AfroEurasian arid type of fauna includes a steppe complex represented by one species. The East Asian type of fauna consists of the Sino-Japanese faunistic complex, including one species.
\end{abstract}

Key words : Tabanids (Diptera, Tabanidae), fauna, zoogeographic characteristics, central Yakutia

\section{INTRODUCTION}

The tabanids, forming the Tabanidae family, included in the brachycerous straight seamed flies suborder (Brachycera, Orthorrapha) of the dipterans, are the largest representatives of the blood-sucking flies of the "gnus" complex, which also include mosquitoes, black flies and biting midges. The northern border of the spread of tabanids passes through the tundra zone. Thus, in Siberia in the Yamalo-Nenets Autonomous District, the upper limit of the spread of tabanids lies north of the cities of Labytnangi and Salekhard (Pavlov and Schepetkin, 1975). On the Taimyr Peninsula, the northern limit of the spread of tabanids passes north of the Dudypta river (between 72 and $73^{\circ} \mathrm{N}$ ), being below the coastline (Polyakov, 1974). In Yakutia, tabanids were found in the near-delta part of the Lena River (Violovich, 1968). In the Chukot Peninsula, tabanids are found almost to the coastline of the East Siberian Sea and are absent only on the coast open to the winds $(15$ to $20 \mathrm{~km}$ inland; Polyakov, 1972, 1974; Pavlov et al., 1985).

The third edition of the book Medical and Veterinary Entomology describes in detail the biology of the horse flies and deer flies (Tabanidae) in warm climates, where they reach sizes up to $30 \mathrm{~mm}$ in length and impact people and animals via direct effects (nuisance, reduced weight gains in animals) and disease agent transmission (Mullens, 2019). In Thailand, horse flies (Diptera : Tabanidae) are widely spread and species identification was carried out on the basis of their morphology, the authors performed DNA identification for the first time (Changbunjong et al., 2018a). The highest proportion of horse flies was collected in Thailand villages (39.13\%), followed by primary forests $(34 \%)$ and secondary forests $(26.87 \%)$. The species diversity of horse flies in primary forests was higher than in other habitats (Changbunjong et al., 2018b). In the central Amazon of Brazil a total of 169 larvae were collected. Catachlorops (C.) rufescens (Fabricius, 1805; Diptera : Tabanidae), from 
which 93 were reared to obtain 64 imagoes (33 males and 31 females). The larval and pupal stages lasted for an average of 88.2 days $( \pm 64.7)$ and 12.6 days $( \pm 2.9$ ), respectively (FerreiraKeppler et al., 2019). Developed a user-friendly morphology description method to ease identification, this guideline can create a bridge between entomologists and veterinary/ technicians, a complete iconography of Tabanus rubidus is given (main vector of surra in Asia; Desquesnes et al., 2018).

According to the leading tabanologist, Olsufyev (1977), on the territory of Russia, there are 114 species and 20 subspecies of 10 genera out of 500 species known for the Palaearctic region. N. A. Violovich was the first to generalize the studies on the species composition of Siberian tabanids (Violovich, 1968), who, based on his own research and data from other scientists for this region, indicated 89 species and subspecies of tabanids of six genera, including 63 in Western Siberia, 52 in Middle Siberia, 43 in Cisbaikalia, 29 in Transbaikalia, 32 in Yakutia, 17 in the north of the Far East, 50 on the continent of the south of the Far East and 25 on the islands.

The fauna of tabanids in various zones of Yakutia has been studied by many researchers. At the same time, Vasyukova (1971) has conducted the most fundamental research in the central and southern parts of the republic. In this region, the author has established the presence of 33 species and four subspecies of tabanids belonging to six genera. However, such a huge area covering more than 1,300 $\mathrm{km}$ requires a detailed study of tabanids in the modern period with an analysis of their zoogeographic structure (Barashkova, 2017; Barashkova and Reshetnikov, 2017), being the aim of this work.

\section{MATERIALS AND METHODS}

The experimental part of the work was carried out in the central natural-climatic zone of Yakutia, the cameral processing of the collected material was carried out at the Yakutsk Research Institute of Agriculture, AllRussian Research Institute of Veterinary Entomology and Arachnology. Stationary studies on the species composition and ecology of insects were carried out in 2000 to 2015 . Faunal collections and surveys of the number of tabanids were carried out through the surveys on animals and their capture using an entomological net with removable sacks (Detinova et al., 1978; Rasnitsyn and Kosovskikh, 1979) and traps (Skufyin, 1951; Pavlov and Pavlova, 1986) during the peak hours of the tabanids' activity throughout the summer season twice per 10 day interval and twice per season every two hours during the day. One account consists of 10 strokes (by the figure of eight) in 10 replications when studying seasonal dynamics of numbers, and in five replications when studying daily activity. When studying the fauna and ecology of tabanids, more than 80 trap counts and about 100 animal counts were carried out. Four thousand four hundred and nine tabanids were collected and identified.

The external structure of tabanids was studied on dry objects previously set on pins, examining them in a manual $12-16$ fold magnifying glass or the MBS-1 binocular magnifying glass. To clarify the correctness of the identification of tabanids, the structure of the terminalia of females was used by the method of Olsufyev (1977). The hindbody terminalia of females were studied in dry insects after keeping them in a humid chamber for $24 \mathrm{~h}$. The terminal third of the hindbody at the level of 4-5 segments was cut off with scissors and boiled for 4-5 $\mathrm{min}$ in a $10 \%$ solution of caustic soda. Then, the end of the hindbody was washed in running water, transferred to a glass slide into a glycerin drop; the terminalia were isolated by entomological pins (VIII sternite and cercus), and preparations were made from them (in glycerin).

The identifying tables of the monographs of Olsufyev (1977) and Violovich (1968) were used when identifying dipterous insects. According to the dominance index (DI), four groups were distinguished using the method of Skufyin (1973) and Olsufyev (1977) as follows : dominant or mass species, constituting $8 \%$ or more of the total number, subdominant or numerous from 2 to $8 \%$, small ones from 0.5 to $2 \%$, and rare less than $0.5 \%$. In identifying the degree of the tabanids' abundance, the gradation developed by Skufyin (1973) was used. The appurtenance of species to a certain faunistic complex was provided as per Olsufyev (1977). The correctness of the identification of the species composition of the collection of blood-sucking flies was confirmed by the Doctor of Biological Sciences, Professor R.P. Pavlov (VNIIVEA, Tyumen). 


\section{RESULTS AND DISCUSSION}

Forest areas with numerous glades and edges, overgrown with various herbs and alases steppe areas characterized by good grass stand serve as pastures for farm animals. On the forest pasture, there are numerous alases with marshy shores, in which breeding of tabanids was observed. The native shore of the lakes is poor in grass vegetation. Peculiar alas meadows are most typical for the Central Yakutian plain. The thermokarst alases of Central Yakutia are formed during the melting of ice layers, which are located in the thickness of loamy soils and subsoils. Such melting is caused by the destruction of forest vegetation after fires. It is accompanied by subsidence (thermokarst) of soils and the formation of alas basin, which for some years has been filled with water. This is called a collapse or thermokarst lake. Then, as the lake's mirror dries out and diminishes, alas meadows with grassy vegetation form around the residual lake.

The thermokarst alas is characterized by a decrease in its surface from the periphery to the center, where the residual, shallow lake is located. Around the lake, vegetation emerges in concentric stripes depending on the degree of soil moisture and its salinity. Close to the water and in shallow water, there is a strip of water-coastal vegetation, which consists of a bed of rushes, calamus and other wetland and marsh plants. Then there is a zone of excessive moisture with sedge-gramineous vegetation (reeds, manna, slough grass, water sedge and others). The sedges retain a significant part of their shoots under the snow and are therefore valued as the best winter feed for herd horses. The next is the zone of medium, and in dry years of insufficient moisture, that is, the widest main part of the alas. The soils here are sod-meadow ones, and saline to some extent. Meadow barley, salt grass and the reed foxtail form the basis of the grass stand. The latter dry zone is located on the periphery of the alas. Here, dry low-yielding herb-alkaligrass salt meadow and herb-quackgrass meadows grow on saline soils, usually with the participation of breviaristate (meadow) barley and foxtail barley. Grass stand is used as pasture forage. Alases served as breeding ground for tabanids on these pastures. One of the alases - the Bakkyam Lake - is a reservoir artificially created for economic purposes. The slopes to this lake are covered with larch forest with rich grass edges. No tabanid breeding places were found here.

As a result of the studies, 21 species and one subspecies of tabanids belonging to two genera have been established on cattle and horse pastures in Central Yakutia, as follows : Chrysops (six species) and Hybomitra (15 species and one subspecies; Table 1). In addition, varieties (dark forms) of two types have been found, namely : Hybomitra bimaculata var. bisignata and $H$. montana var. flaviceps. As can be seen from Table 1, in Central Yakutia, the Hybomitra genus is distinguished by the greatest species diversity. Hybomitra montana montana (DI 45.29\%), $H$. lundbecki lundbecki (DI 24.97\%) and $H$. ciureai (DI $11.20 \%$ ) are the dominant ones, $H$. arpadi (DI 5.85\%), $H$. nitidifrons (DI 4.03\%) and $H$. nigricornis (DI 2.97\%) subdominant. In total, these species accounted for $94.31 \%$ of the collections. Two more species $H$. lurida (DI $1.88 \%$ ) and $H$. lundbecki sibiriensis (DI $1.13 \%$ ) were small in number, accounting for $3.1 \%$ in the collections. The remaining 13 species and one subspecies refer to the group of rare ones and make up $2.59 \%$ in the collections.

According to the Olsufyev's (1977) noogeographic classification, the fauna of the tabanids of central yakutia, which is part of the middle taiga subzone, is of mixed nature, since it is represented by three types of Palearctic fauna, namely, Boreurasian (19 species, one subspecies), Afro-Eurasian arid (one species) and East-Asian (one species) ones. The Boreurasian type is distinguished by the greatest species diversity. The Boreurasian fauna species belong to four faunistic complexes as follows : tundra two species, taiga 14 species and one subspecies, East Siberian forest one species and forest steppe two species (Table 2). As follows from the above data, the taiga faunistic complex is the most representative one, including three fauna options, namely, directly taiga or nominative, taiga-forest and East Siberian taiga. By the number of the collected animal units, the species of the taiga-forest option dominate $(72.42 \%)$, which include two absolutely dominant species (Hybomitra montana montana and $H$. lundbecki lundbecki). All three subdominant species belong to the taiga faunistic complex, two of which are directly taiga (Hybomitra arpadi and H. nigricornis) and 
Table 1. Species composition of tabanids on pastures of Central Yakutia

\begin{tabular}{|c|c|c|c|c|}
\hline \multirow{2}{*}{$\begin{array}{l}\text { Item } \\
\text { No. }\end{array}$} & \multirow[t]{2}{*}{ Species } & \multicolumn{2}{|c|}{ No. of tabanids } & \multirow{2}{*}{$\begin{array}{l}\text { Degree of } \\
\text { abundance }\end{array}$} \\
\hline & & $\begin{array}{c}\text { No. of } \\
\text { species }\end{array}$ & $\begin{array}{l}\mathrm{CI} \\
(\%)\end{array}$ & \\
\hline & Chrysopsinae subfamily & & & \\
\hline & Chrysopsini clan & & & \\
\hline & Chrysops Mg. genus & & & \\
\hline \multicolumn{5}{|c|}{ 1. Chrysops s. str. Subgenus } \\
\hline 1. & Chr. (s. str.) nigripes Ztt. & 12 & 0.27 & + \\
\hline 2. & Chr. (s. str.) divaricatus Lw. & 5 & 0.11 & + \\
\hline 3. & Chr. (s. str.) validus Lw. & 12 & 0.27 & + \\
\hline 4. & Chr. (s. str.) relictus Mg. & 3 & 0.06 & + \\
\hline 5. & Chr. (s. str.) ricardoae jakutensis Ols. & 9 & 0.20 & + \\
\hline \multicolumn{5}{|c|}{ 2. Heterochrysops Kröb. Subgenus } \\
\hline \multirow[t]{5}{*}{6.} & Chr. (H.) vanderwulpi Kröb. & 1 & 0.03 & + \\
\hline & Tabaninae subfamily & & & \\
\hline & Tabanini tribe & & & \\
\hline & Hybomitra End. genus & & & \\
\hline & Hybomitra s. str. subgenus & & & \\
\hline 1. & H. (s. str.) sexfasciata Hine. & 21 & 0.47 & + \\
\hline 2. & H. (s. str.) olsoi Takah. & 9 & 0.20 & + \\
\hline 3. & H. (s. str.) arpadi Szil. & 258 & 5.85 & +++ \\
\hline 4. & H. (s. str.) pavlouskii Ols. & 4 & 0.09 & + \\
\hline 5. & H. (s. str.) tarandina L. & 5 & 0.11 & + \\
\hline 6. & H. (s. str.) aequetincta Beck. & 3 & 0.06 & + \\
\hline 7. & H. (s. str.) lurida Flln. & 83 & 1.88 & ++ \\
\hline 8. & H. (s. str.) nitidifrons nitidifrons Szil. & 178 & 4.03 & +++ \\
\hline 9. & H. (s. str.) distinguenda contigua Ols. & 21 & 0.47 & + \\
\hline 10. & H. (s. str.) ciureai Seg. & 494 & 11.21 & ++++ \\
\hline 11. & H. (s. str.) muehlfeldi Br. & 3 & 0.06 & + \\
\hline 12. & H. (s. str.) bimaculata var. bisignata Jaenn. & 1 & 0.02 & + \\
\hline 13. & H. (s. str.) nigricornis Ztt. & 131 & 2.97 & +++ \\
\hline 14. & H. (s. str.) lundbecki lundbecki Lyn. & 1,101 & 24.97 & ++++ \\
\hline 14a. & H. (s. str.) lundbecki sibiriensis Ols. & 50 & 1.13 & ++ \\
\hline 15. & $H$. (s. str.) montana montana $\mathrm{Mg}$. & 1,997 & 45.29 & ++++ \\
\hline \multirow[t]{2}{*}{$15 a}$. & H. (s. str.) montana var. flaviceps Zett. & 8 & 0.18 & + \\
\hline & Total : 21 species and one subspecies & 4,409 & 100.0 & \\
\hline
\end{tabular}

Note : ++++- large, +++- numerous, ++- limited and +- rare species.

one is East Siberian taiga. (H. nitidifrons nitidifrons). Only one dominant species (Hybomitra ciureai) represents the forest-steppe fauna.

The fauna of the Central Yakutian tabanids is enriched due to the rare species that are not typical of this area, whose penetration through river valleys is quite likely both from the north ( $H$. aequetincta) and from the south $(\mathrm{Chr}$. Ricardoae jakutensis). Violovich (1968), Vasyukova (1971), Olsufyev (1977), etc. paid attention to the significant penetration of species to the north and south along the valleys of large rivers. Thus, the Chrysops ricardoae jakutensis Siberian-Mongolian steppe species has a torn distribution area : it is found in the steppes of the extreme south of Siberia and in the steppe areas of Central Yakutia. It is absent in the taiga regions of Central Siberia. The Hybomitra aequetincta tundra species, typical of high latitudes, has been found on the flat landscapes of Central Yakutia.

Most of the species in Central Yakutia are found on the territory of Russia from its western to eastern borders (14 species), seven species and one subspecies are representatives of East Siberian taiga, East Siberian forest, SiberianMongolian and Sino-Japanese fauna, and most of these species are small in number. It should be noted that the $H$. lundbecki lundbecki and $H$. lundbecki sibiriensis subspecies on the territory of Central Yakutia are found together i. e. there is a sympatric distribution, which is not consistent with the data of Olsufyev (1977), who indicated only $H$. lundbecki sibiriensis for Yakutia, but is consistent with the results of the studies of Vasyukova (1971).

The tabanids of Central Yakutia are characterized by individual variability in the females' colouring largely depending on adverse 
Table 2. Zoogeographic characteristics of tabanids of Central Yakutia

\begin{tabular}{|c|c|c|c|c|c|}
\hline \multirow[t]{3}{*}{ Faunistic complex } & \multirow{3}{*}{$\begin{array}{l}\text { Option of the } \\
\text { faunistic complex }\end{array}$} & \multicolumn{4}{|c|}{ Collected } \\
\hline & & \multicolumn{2}{|c|}{ Species } & \multicolumn{2}{|c|}{ Animal units } \\
\hline & & Number & $\begin{array}{l}\mathrm{CI} \\
(\%)\end{array}$ & Number & $\begin{array}{l}\text { CI } \\
(\%)\end{array}$ \\
\hline \multicolumn{6}{|c|}{ I. Boreurasian fauna type } \\
\hline \multirow[t]{3}{*}{ Tundra } & Nominative $(H$. aequetincta) & 1 & 4.54 & 3 & 0.07 \\
\hline & Tundra-taiga (H. sexfasciata) & 1 & 4.54 & 21 & 0.47 \\
\hline & Total in the complex & 2 & 9.08 & 24 & 0.54 \\
\hline \multirow[t]{4}{*}{ Taiga } & $\begin{array}{l}\text { Nominative (Chr. nigripes, } \\
\text { Chr. divaricatus, } H \text {. arpadi, } \\
\text { H. tarandina and } H \text {. nigricornis) }\end{array}$ & 5 & 22.74 & 411 & 9.33 \\
\hline & $\begin{array}{l}\text { Taiga-forest (H. lurida, H. muehlfeldi, } \\
H . \text { bimaculata var. bisignata, } H . \\
\text { lundbecki lundbecki, } H \text {. montana } \\
\text { montana, } H . \text { montana var. flaviceps) }\end{array}$ & 5 & 22.74 & 3193 & 72.42 \\
\hline & $\begin{array}{l}\text { East Siberian taiga (Chr. validus, } \\
\text { H. olsoi, H. pavlovskii, H. lundbecki } \\
\text { sibiriensis, H. nitidifrons nitidifrons) }\end{array}$ & 5 & 22.74 & 253 & 5.74 \\
\hline & Total in the complex & 15 & 68.22 & 3857 & 87.48 \\
\hline East Siberian forest & $\begin{array}{l}\text { Nominative } \\
\text { (H. distinguenda contigua) }\end{array}$ & 1 & 4.54 & 21 & 0.47 \\
\hline \multirow[t]{2}{*}{ Forest-steppe } & $\begin{array}{l}\text { Nominative } \\
\text { (Chr. relictus, H. ciureai) }\end{array}$ & 2 & 9.08 & 497 & 11.27 \\
\hline & Total in the type & 20 & 90.92 & 4399 & 99.77 \\
\hline \multicolumn{6}{|c|}{ II. Afro-Eurasian arid type of fauna } \\
\hline Steppe & $\begin{array}{l}\text { Siberian-Mongolian } \\
\text { (Chr. ricardoae jakutensis) }\end{array}$ & 1 & 4.54 & 9 & 0.20 \\
\hline $\begin{array}{l}\text { III. East-Asian type } \\
\text { Japanese-Chinese }\end{array}$ & $\begin{array}{l}\text { Nominative } \\
\text { (Chr. (H.) vanderwulpi) }\end{array}$ & 1 & 4.54 & 1 & 0.03 \\
\hline
\end{tabular}

weather conditions. Thus, in 2000 and 2001, tabanids of almost all species had significantly darker colour, up to the disappearance of the brown spots on the abdomen ( $H$. montana var. flaviceps and $H$. bimaculata var. bisignata), while the body seemed more intensely pubescent with hairs. All this greatly hampered their identification. In 2002, the colouration of females practically did not differ from the descriptions given in the monograph by Olsufyev (1977), and tabanids were easily identified. The significant melanization of the body of tabanids in the northern regions was indicated by many researchers who conducted research in these conditions (Lutta, 1970, 1979; Vasyukova, 1971; Polyakov, 1974; Lutta and Bykova, 1979, 1982).

\section{CONCLUSION}

Thus, 21 species and one subspecies of tabanids have been established on the farm animals' pastures in the middle taiga zone of Central Yakutia. The tabanid fauna on forest pastures is more diverse $(21$ species and one subspecies) than on steppificated ones (14 species and one subspecies), which is due to rare species. The following six species are the most numerous and dominant in the pastures : Hybomitra montana montana, $H$. lundbecki lundbecki, $H$. ciureai, $H$. arpadi, $H$. nitidifrons nitidifrons, $H$. nigricornis, whose total dominance index amounted to $81.46 \%$ of the collections. Tabanids of three types of fauna and six faunistic complexes are distributed in Central Yakutia. Representatives of the Boreurasian taiga fauna play the dominant role both in qualitative diversity and abundance.

\section{REFERENCES}

Barashkova, A. I. (2017). The fauna of tabanids (Diptera : Tabanidae) of the agrocenosis of Central Yakutia. Agrarian Bulletin of the Urals 7 : 12-15.

Barashkova, A. I. and Reshetnikov, A. D. (2017). The effectiveness of the use of traps in the fight against tabanids (Diptera : Tabanidae) on alas pastures. Agrarian Bulletin of the Urals 1 : 4-7.

Changbunjong, T., Bhusri, B., Sedwisi, P., 
Weluwanarak, T. and Ruangsittichai, J. (2018a). Species identification of horse flies (Diptera : Tabanidae) in Thailand using DNA barcoding. Vet. Parasitol. 259 : 35-43. DOI : https://doi.org/10.1016/j.vetpar.2018. 07.002.

Changbunjong, T., Sedwisi, P., Weluwanarak, T., Nitiyamatawat, E. and Chareonviriyaphap, T. (2018b.) Species diversity and abundance of Tabanus spp. (Diptera : Tabanidae) in different habitats of Thailand. J. Asia-Pacific Entomol. 21 : 134-139. DOI : ht tps://doi.org/10.1016/ j.aspen.2017.11.013.

Desquesnes, M., Wongthangsiri, D., Jittapalapong, S. and Chareonviriyaphap, T. (2018). Guidelines for user-friendly iconographic description of hematophagous flies' external morphology. Application to the identification of Tabanus rubidus (Wiedemann, 1821) (Diptera : Tabanidae). J. Asia-Pacific Entomol. 21 : 807-822. DOI : ht tps://doi.org/10.1016/ j.aspen.2018.06.005.

Detinova, T. S., Rasnitsyn, S. P., Markovich, N. Ya., Kupriyanova, E. S., Aksenova, A. S., Anufrieva, V. N., Bandin, A. I., Vinogradskaya, O. N. and Zharov, A. A. (1978). Unification of methods for recording the number of bloodsucking dipterous insects. Med. Parasitol. and Parasitic Dis. 47 : 84-92.

Ferreira-Keppler, R. L., Rafael, J. A. and Martins, R. T. (2019). Morphology and bionomy of immature stages and description of the adult male of Catachlorops (C.) rufescens (Fabricius, 1805) (Diptera: Tabanidae) from the Central Amazon, Brazil. Zoologischer Anzeiger 278 : 57-65. DOI : https://doi.org/ 10.1016/j.jcz.2018.11.004.

Lutta, A. S. (1970). Tabanids of Karelia. Leningrad : Nauka.

Lutta, A. S. (1979). Adaptive features in tabanids common in areas of the European North of the USSR. In : 7th Symposium on Biological Problems of the North. Apatity. pp. 39-43.

Lutta, A. S. and Bykova, H. I. (1979). Dark colouring of tabanid covers as an adaptation to the conditions of the North. In : 7th Symposium on Biological Problems of the North. Apatity. pp. 124-126.
Lutta, A. S. and Bykova, H. I. (1982). Tabanids (Tabanidae family) of the European North of the USSR. Leningrad : Nauka.

Mullens, B. A. (2019). Chapter 16 : Horse Flies and Deer Flies (Tabanidae). In : Medical and Veterinary Entomology. Academic Press. pp. 327-343. DOI : https://doi.org/10.1016/ B978-0-12-814043-7.00016-9.

Olsufyev, N. G. (1977). The fauna of the USSR : Diptera insects, Vol. 7, Issue 2. Leningrad : Nauka.

Pavlov, S. D. and Schepetkin, V. A. (1975). Bloodsucking two-winged insects (gnus) and reindeer gadfly of the Yamalo-Nenets Autonomous District. In : Proc. Agricultural Research Institute of Northern Trans-Urals, Issue VI. Tyumen. pp. 71-80.

Pavlov, S. D., Tsapyrin, Yu. N. and Tikhomirov, S. M. (1985). The study of the harmlessness of ultra-small volume spraying of animals with DDVF oil solutions. In : The issues of the veterinary arachno-entomology : VNIIVEA scientific and technical bulletin, Issue 27. Tyumen. pp. 11-14.

Pavlov, S. D. and Pavlova, R. P. (1986). Guidelines for the use of traps for collecting, counting and exterminating of tabanids on pastures. Moscow.

Polyakov, V. A. (1972). Tabanids of forest tundra as possible carriers of microorganisms. Veterinariya 6 : 51-53.

Polyakov, V. A. (1974). Tabanids of the North of the Asian part of the USSR and the protection of reindeer from them. Magadan : Knizhnoe izdatelstvo.

Rasnitsyn, S. P. and Kosovskikh, V. L. (1979). Improved method of accounting for the abundance of mosquitoes with a net around a person and comparing it with the Campanula pulla L.. Med. Parasitol. and Parasitic Dis. 48 : 18-24.

Skufyin, K. V. (1951). Experience of using a stuffed trap for tabanids. Zool. J. $30: 378-380$.

Skufyin, K. V. (1973). Methods of Collecting and Studying Tabanids. Leningrad : Nauka.

Vasyukova, T. T. (1971). To the issue of the study of tabanids (Diptera : Tabanidae) of Yakutia. In : Harmful Insects and Worms of Yakutia. Yakutsk. pp. 50-55.

Violovich, N. A. (1968). Siberian Tabanids. Novosibirsk : Nauka. 